\title{
THE MAKING OF EBOLA... MEDIALNE NARRACJE O EPIDEMII W ZACHODNIEJ AFRYCE
}

Pierwszy przypadek zachorowania na ebolę, od którego rozpoczęła się ostatnia, trwająca kilkanaście miesięcy epidemia tej choroby, odnotowano pod koniec 2013 roku w odległym, południowym rejonie Gwinei. Jego ofiarami byli roczny chłopiec o imieniu Emile oraz kolejni członkowie jego rodziny. W marcu 2014 roku pojedyncze przypadki zachorowań odnotowano w Konakry, co wzbudziło popłoch wśród mieszkańców miasta, ze względu na dużą gęstość zaludnienia, choć wciąż łudzono się, że być może chodzi o wiele mniej groźną gorączkę Lassa, której symptomy przypominają ebolę. W połowie tego miesiąca przeprowadzono testy w laboratorium we Francji, które potwierdziły obecność wirusa śmiertelnej choroby. 25 marca Światowa Organizacja Zdrowia (WHO) potwierdziła wybuch epidemii na południu Gwinei oraz zwróciła uwagę na podejrzane przypadki zachorowań w sąsiednich krajach, czyli w Liberii oraz Sierra Leone. W przeciągu trzech miesięcy od momentu potwierdzenie przez WHO wybuchu epidemii odnotowano łącznie kilkaset przypadków w Liberii, Sierra Leone, Ghanie, Mali oraz w Nigerii i Senegalu, jednak przypuszcza się, że liczba zachorowań mogła być o wiele większa, ponieważ nie wszyscy chorzy zostali zgłoszeni przez bliskich odpowiednim służbom. Zatem nie wszystkie przypadki zachorowań zostały odnotowane oraz znalazły odzwierciedlenie w już i tak bijących na alarm statystykach.

Społeczność międzynarodowa dowiedziała się o istnieniu eboli w 1976 roku, kiedy w ówczesnym Zairze (obecnie Demokratyczna Republika Konga) oraz w Sudanie wybuchła pierwsza epidemia tej choroby. Choć bardzo mocno dotknęła ona tamtejsze społeczności, nie spotkała się z zainteresowaniem mediów zachodnich. Owszem, była śmiertelna, a wirus okazał się bardzo zaraźliwy, jednak dopóki ,jądro ciemności” znajdowało się na krańcach świata, nie przemawiało to do wyobraźni ludzi Zachodu. Sytuacja zmieniła się dopiero przeszło dwie dekady później, kiedy ebola wykryta została wśród makaków przywiezionych do laboratorium w Reston w stanie Viriginia. Choć ten konkretny szczep nie okazał się groźny dla ludzi, wydarzenie to stało się kanwą bestsellerowej powieści Richarda Prestona Hot Zone. Tym samym, ujęta w karby narracji ebola została uosobieniem groźnej epidemii, która jest w stanie zagrozić ludzkości. Dużą rolę w procesie symbolicznego zawłaszczenia wirusa odegrał film Epidemia, czyli ekranizacja powieści Prestona z 1995 roku, w której główne role zagrali Dustin Hoffman oraz Morgan Freeman. Film skupił uwage mediów na tym egzotycznym i - przynajmniej potencjalnie - śmiertelnie groźnym dla ludzkości wirusie. Jak pisze lekarz i antropolog Paul Farmer:

Nowoczesne środki komunikacji, w tym druk oraz media przekazu, odegrały kluczową rolę w procesie konstruowania eboli - jeśli przyjrzeć się statystykom małego gracza na długiej liście śmiertelnych chorób występujących w Zairze - jako nowej choroby zakaźnej... Dziennikarze oraz pisarze napisali dobrze sprzedające się książki na temat małej, ale przerażającej plagi, co okazało się źródłem zysków kinowych. Dlatego, symbolicznie i dosłownie, ebola szerzy się jak ogień - jak potencjalnie zagrożenie bez granic. Tak oto powstała. ${ }^{1}$

${ }^{1}$ P. Farmer, Social Inequalities and Emerging Infectious Deseases, „Emerging Infectious Diseases" 1996, t. 2, s. 262. 
Farmer słusznie zauważa, że media zachodnie przeceniają zagrożenie, jakim jest ebola. Faktycznie jest to choroba o bardzo wysokim wskaźniku umieralności, jednak o wiele więcej osób umiera na wyleczalną malarię oraz gruźlicę, ponieważ w wielu krajach leki na nie są trudno dostępne ${ }^{2}$. Czynnikiem decydującym o sposobie postrzegania eboli było jednak to, że nie jest chorobą endemiczną, w związku z czym potencjalnie może stanowić zagrożenie dla cywilizacji zachodniej.

Nie jestem w stanie ocenić skuteczności działań zapobiegawczych podjętych przez organizacje międzynarodowe oraz rządy państw zachodnich, choć raczej dominuje przekonanie, że ich reakcja była spóźniona, a podjęte akcje źle skoordynowane ${ }^{3}$. W niniejszym artykule chciałabym jednak poddać analizie dyskurs mediów amerykańskich na temat przyczyn epidemii i zestawić go z wypowiedziami prezydenta Obamy skierowanymi do obywateli amerykańskich oraz mieszkańców krajów dotkniętych ebolą. W przypadku epidemii wirusa takiego jak ebola, gdzie bardzo ważna jest szybka reakcja społeczności międzynarodowej, rzetelność informacji przekazywanych przez media masowe odgrywa niezwykle ważną rolę. Tymczasem podczas trwania ostatniej epidemii media przez wiele miesięcy bagatelizowały wezwania organizacji międzynarodowych do podjęcia działań. Zwróciły one uwagę na problem dopiero wtedy, kiedy pierwsze przypadki zachorowań odnotowano w Stanach Zjednoczonych a następnie w Europie, a dodatkowo ich sposób przedstawiania epidemii pozostawiał wiele do życzenia.

Szczególnie media konserwatywne (choć nie wyłącznie) oraz tabloidy prześcigały się w spekulacjach na temat rzekomego zagrożenia wybuchem epidemii w Stanach oraz stopnia przygotowania amerykańskiej służby zdrowia na wypadek pojawienia się większej ilość przypadków. Jak pokazał raport niezależnej organizacji zajmującej się monitorowaniem środków masowego przekazu Media Matters for America ${ }^{4}$, doprowadziło to do medialnej paniki. Co więcej, ze sporządzonego przez Paw Research Center ${ }^{5}$ raportu wynika, że pomimo ogromnej ilości godzin poświęconych w mediach tematowi eboli większość Amerykanów nie znała na jej temat podstawowych faktów, takich jak choćby drogi zakażenia. Jednak, aby zrozumieć reakcję opinii publicznej w Stanach Zjednoczonych, należałoby się przyjrzeć także sposobowi przedstawiania przebiegu epidemii w krajach, które dotknęła ebola. Niepokojące jest bowiem to, że na podstawie przekazywanych informacji można było dojść do wniosku, że przyczyną szerzenia się wirusa są zwyczaje i kultura mieszkańców Zachodniej Afryki. Autorzy wielu tekstów medialnych zamiast przedstawić społeczno-polityczne przyczyny wybuchu epidemii, kreowali obraz Afryki jako „rezerwuaru eboli“, którego mieszkańcy kultywują tradycje powodujące przenoszenie się śmiertelnego wirusa, zatem - w domyśle - ponoszą odpowiedzialność za zaistniałą sytuację i w związku z tym nie maja oni prawa do pomocy.

\section{Zachodnie media}

W maju 2014 roku podczas spotkania z dziennikarzami poświęconego wyborom do Parlamentu Europejskiego, Jean-Marie Le Pen stwierdził, że epidemia eboli może „rozwiązać” problem nielegalnych imigrantów z Afryki w przeciągu trzech miesięcy ${ }^{6}$. Oczywiście, można traktować jego stwierdzenie jako marginalny wybryk, ponieważ jest to polityk, który wielokrotnie karany był za swoje rasistowskie wypowiedzi, jednak

${ }^{2}$ Ibidem, s. 259-269.

${ }^{3}$ L. Garrette, Ebola'a Lesson. How the WHO Mishandled the Crisis, „Foreign Affairs” 2015 , t. 94 , nr 5, s. 80-107.

${ }_{5}^{4} \mathrm{https}: / /$ mediamatters.org/stories-and-interests/ebola.

$5 \mathrm{~S}$. Motel, Ebola ranks among highest in news interest since 2010, http://www. pewresearch.org/fact-tank/2014/10/21/ebola-ranks-among-highest-in-news-interest-since-2010/

${ }^{6} \mathrm{~K}$. Willsher, Jean-Marie Le Pen suggests Ebola as solution to global population explosion, https://www.theguardian.com/world/2014/may/21/jean-marie-le-pen-ebola-populationexplosion-europe-immigration 
tego typu topikę odnajdziemy w wielu tekstach medialnych. Prasa oraz stacje telewizyjne przekazując informacje na temat epidemii eboli, skupiły się przede wszystkim na bezpieczeństwie obywateli Stanów Zjednoczonych i Europy.

Stan medialnej paniki podsycany był przez wszystkie stacje telewizyjne, choć przodowało w tym Fox News, której prezenterzy starali się upolitycznić epidemię, wpisując ją w kontekst ówczesnej sytuacji politycznej w USA. W programach publicystycznych pojawiały się między innymi wypowiedzi, które sugerowały, że prezydent Barack Obama planował wysłać żołnierzy do Liberii, ponieważ tak naprawdę nie czuje się „przywódcą obywateli amerykańskich” (Keith Ablow, Fox News Radio, The John Gibson Show). Dawano też do zrozumienia, iż wiedziony wyrzutami sumienia z powodu historii niewolnictwa w Ameryce próbuje ukarać własnych obywateli, narażając ich na zarażenie się wirusem (Laura Ingraham, Fox News; Michael Savage, prezenter radiowy) lub, że nie wstrzymuje lotów z Afryki Zachodniej, ponieważ jest czarny, w związku z czym nie byłoby to politycznie poprawne (The Rush Limbaugh Show, program radiowy $)^{7}$. Sugerowano również, że nie można ufać uspokajającym zapewnieniom dyrektora CDC Thomasa Friedenao, który twierdził, iż USA nie grozi epidemia, ponieważ CDC powiązane jest politycznie z administracją Obamy (Steve Doocky, Fox\&Friends; Bill O’Reilly, Fox News $)^{8}$. Pierwszych przypadków zarażenia ebolą na terenie kraju próbowano również użyć jako argumentu przeciwko przyjmowaniu imigrantów (Ingraham i Limbaugh), ponieważ „nielegalni imigranci” zamiast udać się do szpitala, mogą chcieć leczyć się u znachorów (Andrea Tantaros, Fox News) ${ }^{9}$. Ebola łączona była również z terroryzmem, czego przykładem były spekulacje Ashleigh Banfield. Prezenterka CNN sugerowała, że ISIS może wysłać swoich członków na tereny, gdzie panuje epidemia, aby potem przerzucić ich w miejsca, w których będą mieli możliwość zarazić innych ludzi ${ }^{10}$. Przy okazji media przypomniały postać Richarda Prestona, który przynajmniej dwukrotnie (CNN, CBS) wystąpił w roli eksperta i nazwał ebolę „Kubą Rozpruwaczem wśród wirusów”"

Ksenofobiczne i rasistowskie treści, wkrótce zebrały żniwo w postaci ataków na emigrantów z Liberii oraz Sierra Leone, nawet tych, którzy w ostatnim okresie nie opuścili terytorium Stanów Zjednoczonych. Aby zwrócić uwagę na problem rasistowskich incydentów $\mathrm{w}$ związku $\mathrm{z}$ ebolą, matka jednej $\mathrm{z}$ gnębionych $\mathrm{w}$ szkole uczennic zapoczatkowała w mediach społecznościowych akcję I AM A LIBERIAN, NOT A VIRUS ${ }^{12}$. Zdarzały się również przypadki, kiedy nakłaniano do odbycia kwarantanny ludzi, którzy odbyli podróż do Afryki. I bynajmniej nie chodziło tu jedynie o pracowników służby zdrowia, ale np. o pracowników, którzy podczas podróży służbowej przebywali w zupełnie innych częściach kontynentu, oddalonych od centrum występowania choroby o tysiące kilometrów.

\section{Afryka jako rezerwuar eboli}

W okresie trwania epidemii w Afryce Zachodniej telewizja PBS opublikowała kilkadziesiąt artykułów, filmów oraz wywiadów z pracownikami służby zdrowia 201019

7 https://mediamatters.org/video/2014/10/03/limbaugh-us-will-never-take-steps-to-stop-ebola/

${ }^{8}$ O'Reilly Ignores Health Care Experts To Lecture CDC's Dr. Tom Frieden On Why U.S. Needs A Travel Ban To Control Ebola, https://mediamatters.org/video/2014/10/16/oreilly-ignoreshealth-care-experts-to-lecture/201195

${ }^{9}$ J. Rothkopf, Andrea Tantaros: Africans infected with Ebola might "seek treatment from a witch doctor”, ,Salon“ 2014, z. 10, https://www.salon.com/2014/10/02/andrea_tantaros_ africans_infectedwith_ebola_might_seek_treatment_from_a_witch_doctor/

${ }^{10}$ CNN concedes Ebola is not in fact 'ISIS of biological agents.'; https://www.Youtube. $\mathrm{com} /$ watch? $=$ XrovH26DlbA

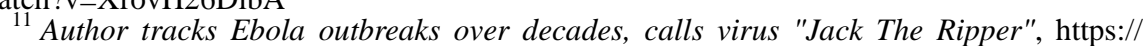
www.youtube.com/watch? $\mathrm{v}=\mathrm{s} 3 \mathrm{nSOjesEMg}$

${ }^{12} \mathrm{~S}$. Cachelle, I AM A LIBERIAN, NOT A VIRUS, https://www.youtube. com/watch? $\mathrm{v}=\mathrm{UEs} 8 \mathrm{xHgBq} 7 \mathrm{~g} \&$ spfreload $=10$ 
i członkami społeczności dotkniętych ebolą. Następnie materiały te złożyły się na film dokumentalny zatytułowany Outbreak, wyemitowany w całości 5 maja 2015 roku. Film wyprodukowany zostały we współpracy z gazetą „The New York Times”, która umieszczała jego fragmenty na swojej stronie internetowej. Wydaje mi się, że stanowią one reprezentatywny materiał do analizy, ponieważ zarówno telewizja PBS jak i „New York Times” cieszą się dużym zaufaniem społecznym i szczyca się swoją reputacją jako wiarygodnych źródeł informacji ${ }^{13} .28$ grudnia 2014 roku PBS opublikowała film na temat „pacjenta zero”, czyli osoby od której przypuszczalnie zaczęła się ostatnia epidemia, a dzień później artykuł How Ebola Roared Back ukazał się na stronie internetowej gazety ${ }^{14}$.

W filmie pracujący w lokalnym ośrodku zdrowia pielęgniarz oraz ojciec chłopca o imieniu Emil relacjonują przebieg epidemii w ich rodzinnej wiosce. Pielęgniarz opowiada, jak zrozpaczony po śmierci żony oraz kilkuletniego syna człowiek krzyczał, że „wioska zabija jego dzieci“, na co on sam odrzekł, że to nie wioska, ale Bóg odebrał mu bliskich. Obaj mężczyźni opowiadają też, jak przekonani byli, że na wioskę rzucono klątwę, w związku z czym odprawione zostały zabiegi magiczne przez lokalnego znachora, których przebieg zaprezentowano na amatorskim, nakręconym telefonem komórkowym filmie. Sposób relacjonowania wydarzeń przez dziennikarzy sugeruje widzowi, że to, z czym mieli do czynienia mieszkańcy wioski, nie było epidemią, ale właściwie plagą, zjawiskiem, którego nie da się racjonalnie wytłumaczyć. Na jednym z kolejnych ujęć pokazana jest palma, z której konarów wylatuje stado nietoperzy (megachiroptera). $\mathrm{Z}$ pozoru jest to banalne ujęcie obrazujące faunę i florę tego regionu, jednak wpisane w ramę narracyjną na temat tajemniczej choroby, klątwy oraz plagi sprawia, że nietoperze urastają do rangi symbolu. Bowiem, jak pisze Susan Sontag, najbardziej przerażające są te choroby, w których zwierzę jest źródłem zakażenia, jak w przypadku wścieklizny, lub te, które ze względu na gwałtowny przebieg i upokarzające symptomy zezwierzęcają człowieka, zapowiadając groźbę śmiertelnego rozkładu ${ }^{15}$.

Bez problemu można znaleźć więcej podobnych przykładów narracji na temat mieszkańców krajów ogarniętych epidemią, którzy są przedstawiani jako zacofani, podejrzliwi względem nowoczesnej medycyny i przywiązani do „tradycyjnych” (czyli będących przeciwieństwem tego, co nowoczesne) rytuałów. W artykule Bushmeat and the Politics of Disgust Mike McGovern pisze o materiale zrealizowanym przez Vice Media poświęconym spożywaniu mięsa dzikich zwierząt w Liberii ${ }^{16}$. W jednej ze scen dziennikarz Kaj Larsen rozmawia z miejscową ludnością przed targiem w Monrovi. Jego rozmówcy rozrywają opalone mięso małpy, którego kawałek spada mu na ubranie, na co dziennikarz reaguje obrzydzeniem mówiąc, że ma na sobie ebolę. McGover zwraca uwagę na klisze kulturowe widoczne w filmie: ebola przenoszona jest przez egzotyczne zwierzęta, mieszkańcy Afryki Zachodniej, którzy nie wierzą w istnienie wirusa eboli, zjadają je, w związku z czym odpowiedzialni są za to, że z pewnością zachorują. Paradoks polega na tym, że prawdopodobnie jedyną osobą, która zaraziła się wirusem odzwierzęco był właśnie Emil.

W tym miejscu chciałabym przyjrzeć się dwóm wypowiedziom prezydenta Obamy udostępnionym na oficjalnym kanale Białego Domu, których tematem była

${ }^{13}$ National Survey Confirms that PBS and Member Stations Are America's Most Trusted Institution and an "Excellent" Use of Tax Dollars for 12th Consecutive Year, http:// www.pbs. org/about/blogs/news/national-survey-confirms-that-pbs-and-member-stations-areamericas most-trus ted-institution-and-an-excellent-use-of-tax-dollars-for-12th-consecutive-year/

${ }^{14}$ K. Sack, S. Fink, P. Belluck, A. Nossiterk, How Ebola Roared Back, http:// www.nytimes.com/2014/12/30/health/how-ebola-roared-back.html

${ }^{15}$ S. Sontag, Choroba jako metafora. AIDS i jego metafory, przeł. J. Anders, Warszawa 1999.

${ }^{16}$ M. McGovern, Bushmeat and the Politics of Disgust, „Cultural Anthropology Journal” 2014, t. 10, http://www.culanth.org/fieldsights/588-bushmeat-and-the-politics-of-disgust 
ebola. Obydwa materiały łączy to, że utrzymane są w poetyce bezpośredniego zwrotu do nadawcy, co ma stworzyć atmosferę wzajemnego zaufania i zrozumienia. Pierwszy z nich pochodzi z dnia 2 września 2014 roku i skierowany jest do obywateli państw Afryki Zachodniej, natomiast drugi z dnia 18 października adresowany jest do obywateli Stanów Zjednoczonych.

W pierwszej wypowiedzi Obama zaczyna od stwierdzenia, że rząd Stanów Zjednoczonych współpracuje $\mathrm{z}$ władzami krajów afrykańskich $\mathrm{w}$ walce $\mathrm{z}$ ebolą oraz podkreśla, że kluczem do pokonania epidemii jest poznanie faktów na jej temat. Chorobą nie można zarazić się tak jak grypą, ponieważ nie przenosi się ona drogą kropelkową, nie można się nią też zarazić od innej osoby, dopóki nie będzie ona wykazywać pierwszych symptomów. Jedyną drogą zarażenia jest kontakt z płynami ustrojowymi osoby chorującej na ebolę lub zmarłej. Podobnie jak lokalne media w Sierra Leone, Liberii, Nigerii i Gwinei, prezydent Obama skupił się w swojej wypowiedzi na przekazaniu informacji dotyczących dróg zakażenia, ponieważ raporty wszystkich organizacji zajmujących się zdrowiem (Lekarze bez Granic, WHO) donosiły, że najczęściej dochodziło do niego w momencie, kiedy bliscy pielęgnowali chorych lub przygotowywali zwłoki zmarłych do pochówku. Zresztą było to jednym z głównych powodów, dla których grupę najbardziej zagrożoną zachorowaniem na ebolę stanowiły kobiety, szczególnie na terenach wiejskich, gdzie sąsiadki pomagały rodzinie w ablucjach.

Możecie postępować zgodnie ze swoją tradycją i oddać cześć tym, których kochacie bez potrzeby narażania życia. Zatrzymanie tej choroby nie będzie łatwe, ale wiemy, jak należy to zrobić. Nie jesteście sami. Razem możemy traktować tych, którzy zachorowali, z szacunkiem i godnością. Możemy ratować życie, a nasze kraje mogą pracować razem nad poprawą publicznej służby zdrowia, aby tego typu epidemia się nie powtórzyła. [...] Będziecie mieć partnera we mnie i w Stanach Zjednoczonych Ameryki. ${ }^{1 f}$

Wypowiedź Obamy jest ostrożna, wyraźnie widać, że waży słowa, z szacunkiem wyraża się o tradycji, ale jednocześnie stanowczo podkreśla znaczenie prewencji, która w tym przypadku oznacza odejście od tej tradycji. Choć film wyraźnie różni się od materiału zrealizowanego przez Vice Media, to oba przekazy mają jednak pewne cechy wspólne, przede wszystkim to, że kultura tradycyjna przedstawiana jest w nich jako pierwszorzędny czynnik ryzyka ${ }^{18}$.

Jak podawało CDC, to właśnie szpitale były jednym z podstawowych źródeł zakażenia ebolą, a jeden na dwudziestu chorych zaraził się wirusem podczas opieki nad tymi chorymi. W związku z czym należałoby uznać, że niewystarczająca infrastruktura placówek publicznej służby zdrowia była czynnikiem, który w największym stopniu przyczynił się do epidemii. Tymczasem większość tekstów medialnych, które dotyczyły jej przyczyn, skupiało się na braku wiedzy i potrzebie edukowania społeczności lokalnych. Przykładem takiego podejścia jest przemówienie prezydenta Obamy, który podkreśla rolę prewencji, aby w zaledwie jednym zdaniu odnieść się do niskiego poziomu służby zdrowia i konieczności jego poprawy w przyszłości. Tendencję do obarczania winą za epidemię lokalnych społeczności widać również w przywoływanym przeze mnie wcześniej filmie zrealizowanym przez telewizję PBS oraz „The New York Times", w którym pokazane są zaniedbane, prowizoryczne domy mieszkańców wioski bez dostępu do bieżącej wody czy elektryczności oraz ośrodek zdrowia pozbawiony jakiejkolwiek infrastruktury pozwalającej na skuteczną pomoc pacjentom.

Po cichu zakłada się, że bieda stanowi esencjonalną część „,kondycji ludzkiej“ w krajach afrykańskich, w wyniku czego społeczności lokalne zwracają się ku obrzędom magicznym. Obyczaj jedzenia mięsa nietoperzy, ale również innych dzikich

${ }^{17}$ President Obama Delivers a Message to West Africans on Ebola, https://www. youtube $. \mathrm{com} /$ watch? $\mathrm{v}=\mathrm{gFKMYY}-2 \mathrm{~A} 2 \mathrm{k}$

${ }^{i 8}$ U. Pellecchia, Do traditions spread Ebola?, „Ebola Response Anthropology Platform”, http://www.ebola-anthropology.net/case_studies/do-traditions-spread-ebola/ 
zwierząt, magiczne praktyki mające na celu oczyszczenie wioski i tym samym pozbycie się plagi, ślepe przywiązanie do rytuałów pogrzebowych oraz nieznajomość choroby przez miejscowego pielęgniarza ukazywane są jako bezpośrednie przyczyny epidemii. Zwrócenie uwagi na obyczaje i kulturę, jako elementy ryzyka, działające wbrew ustalonej i usankcjonowanej przez autorytet zachodniej medycyny wiedzy na temat chorób zakaźnych, maskuje prawdziwe przyczyny ich szerzenia się. Zrealizowany w dobrej wierze materiał przedstawia nie tyle konkretną wioskę, ale jak pisał Mbembe „Afrykę jako ideę, jako pojęcie, które historycznie służyło i nadal służy jako polemiczny argument na rzecz pragnienia Zachodu do potwierdzenia własnej inności od reszty świata"19.

Okcydentalny punkt widzenia pozwala nam dostrzec brak infrastruktury medycznej, ukazuje także pracownika służby zdrowia, który po raz pierwszy zetknął się z bardzo rzadką i śmiertelną chorobą dziesiątkującą mieszkańców wioski, jednak nie zmusza nas do zadania pytań o przyczyny tego stanu rzeczy. Wszak sytuacja, w jakiej się znalazł ów pracownik niewiele różniła się od okoliczności zakażenia ebolą pielęgniarki ze szpitala w Dallas ${ }^{20}$. Kobieta nie rozpoznała charakterystycznych symptomów, czyli wysokiej gorączki i bólów brzucha i odesłała Thomasa Erica Duncana do domu, choć kilka dni wcześniej wrócił z Liberii. W ten sposób chory mógł zarazić kolejne osoby. Zresztą kilkanaście dni później przyjęto go jednak na oddział, gdzie po kilku dniach zmarł, wcześniej jednak zaraził jedną z opiekujących się nim pielęgniarek. W miarę sprowadzania do kraju chorujących w Afryce Amerykanów, którzy pojechali tam jako wolontariusze, personel pielęgniarki zaczął domagać się przeprowadzenia szkoleń oraz opracowania staranniejszych protokołów bezpiecznej opieki nad zarażonymi wirusem pacjentami. Choć sytuacja pielęgniarza z wioski była analogiczna do tej, która miała miejsce w Dallas, to przez zachodnie media przypadki te oceniane były zupełnie inaczej, a różnica ta polegała na podejściu do medycyny. Zachodnia medycyna traktowana jest bowiem nie jako konstrukt kulturowy, ale jako proces akumulacji wiedzy poprzez wypracowanie technik mających za zadanie eliminowanie błędów oraz falsyfikowanie stwierdzeń, w wyniku czego dochodzi się do wytworzenia obiektywnej wiedzy ${ }^{21}$. Przekonanie o uprzywilejowanej pozycji medycyny - nawet jeśli dochodzi na jej gruncie do błędów - bierze się z założenia, że wyznacza ona granice pomiędzy uniwersalną wiedzą a wierzeniami, które opierają się na przypuszczeniach i dlatego są bardziej podatne na błędy. Różnicę tę widać wyraźnie w przemówieniu prezydenta Obamy do Amerykanów, które posiada dość podobną strukturę, jak komunikat skierowany do mieszkańców krajów Afryki Zachodniej, jednak nie zaczyna się od nawiązania do tradycji i wierzeń, ale od afirmacji roli medycyny jako nauki: ,ebola jest poważną chorobą, jednak nie możemy popadać w histerię ani poddawać się lękowi, ponieważ utrudnia to przekazanie ludziom informacji, których potrzebują. Musimy kierować się wiedzą naukową i pamiętać o podstawowych faktach" ${ }^{22}$.

Poza tym, w pierwszym nagraniu Obama skupił się na środkach prewencji, natomiast $\mathrm{w}$ wideo, którego odbiorcami mają być obywatele amerykańscy, mówił o leczeniu eboli. Pojawienie się pierwszych przypadków zachorowań na ebolę w Stanach Zjednoczonych rozpoczęło dyskusję na temat możliwości wyprodukowania leków oraz szczepionek przeciwko tej chorobie. Choć wirus znany jest od wielu lat, a od czasu ataków na World Trade Center znajduje się na liście A zagrożeń terrorystycznych, jednak nie prowadzono nad nim badań, ponieważ większość wcześniejszych epidemii

${ }^{19}$ A. Mbembe, On the Postcolony, Berkeley 2001, s. 2.

${ }^{20}$ Texas nurse who had worn protective gear tests positive for Ebola, 2.12.2000, http://edition.cnn.com/2014/10/12/health/ebola/

${ }^{21}$ J. Savage, Ethnography and health care, "British Medical Journal", z. 2. 12, 2000; http://www.ncbi.nlm.nih.gov/pmc/articles/PMC1119117

${ }^{22}$ Weekly Address: What You Need to Know About Ebola, https://www.youtube. com/watch?v=7u08u8GA_rg 
nie miała wielkich rozmiarów, liczba zgonów najczęściej wynosiła około kilkudziesięciu, a łączna liczba ofiar nie przekroczyła 300 osób. ${ }^{23}$ Pierwsze przypadki zachorowań na terenie Stanów Zjednoczonych i w Europie uświadomiły mieszkańcom krajów zachodnich, że ebola nie respektuje kontroli paszportowych na lotniskach, co bardzo dobrze podsumowane zostało w popularnej na You Tube piosence Rucka Rucka Ali.

Every shitty little village in Africa has Ebo-la

Every city in America is getting it now

Just go with it bruh

Airports

Check if he's Black

He could have Ebola so send him back

In fact keep a eye on the Black Eye Peas

Mostly Black \& Guy

Don't worry about Peas

$\&$ the Cosbys could have Ebola also Oprah

Let's just close up Detroit til this crisis is contained don't the Obamas

on the plane cuz they black

They could have Ebola

Might as well also watch for Ayrabs

If they have a brown face

We'll keep em safe in Guantanamo Bay

I'm sorry for everybody for the drama but we're gonna get Ebola

if we let black people in

Ebola's not a country in Africa

It's the whole continent

I have Ebo-la-la-la-la-la

You have Ebo-la-la-la-la-la

Obama hasEbo-la-la-la-la-la ${ }^{24}$

Wielu komentatorów podkreślało, że eksperymentalne leki i szczepienia próbowano wprowadzić na rynek od kilku lat, jednak żaden $\mathrm{z}$ nich nie został poddany testom klinicznym ze względu na brak finansowania. Jedną z przyczyn tego stanu rzeczy było to, że do epidemii, która rozpoczęła się w 2013 roku, nie istniało na nie zapotrzebowanie, więc koszty ich wdrożenia z całą pewnością by się nie zwróciły. Dopiero podanie eksperymentalnego leku ZMapp lekarzowi Kentowi Brantly’owi, amerykańskiej misjonarce Nancy Writebol, brytyjskiemu pielęgniarzowi Williamowi Pooley oraz hiszpańskiemu księdzu Miguelowi Pajares, zwróciło uwagę na możliwość wyprodukowania nowego preparatu ${ }^{25}$. Warto w tym kontekście podkreślić jeszcze, że dyskusje na temat możliwości wprowadzenia do obrotu leków przeciwko eboli, które toczyły się w mediach, dotyczyły przede wszystkim opłacalności ich produkowania oraz wzmożonego zainteresowania wirusem przez firmy farmaceutyczne na fali połowicznego ponieważ Pajares zmarł mimo podania leku - sukcesu ZMapp. W tym kontekście wytworzył się nowy obraz eboli jako zjawiska podlegającego komercjalizacji, o czym świadczy fakt, że w prace nad stworzeniem leku zaangażowało się Fuji Film. Firma ta nie była do tej pory kojarzona $\mathrm{z}$ rynkiem farmaceutycznym, ale epidemia miała miejsce $\mathrm{w}$ momencie załamania się rynku fotograficznego ${ }^{26}$. Inną firmą zaangażowaną w pro-

${ }^{23}$ Outbreaks Chronology: Ebola Virus Disease, Centers for Desease Control and Prevention, http://www.cdc.gov/vhf/ebola/outbreaks/history/chronology.html

${ }^{24}$ Rucka Rucka Ali, Ebola (La La); https://www.youtube.com/watch?v=hiSsrEg3tks

${ }^{25} \mathrm{Na}$ osobną analizę zasługują kontrowersje dotyczące tego, komu należy podać dawkę serum przeciwko eboli, jednak zainteresowanych tym tematem odsyłam do artykułu A. Benton, The Not-So-Secret-Serum, „Dissent”, 16.08.2014, https://www.dissentmagazine.org/blog/ secretserum-ebola-africa-racism

${ }^{26}$ Ebola Drugs in the Works: ZMapp, TKM-Ebola, Brincidofovir, Bloomberg TV, https:// www.youtube.com/watch?v=Iq-ALJ0WbEE 
dukcję preparatu przeciwko eboli była Tekmira, której środek o nazwie TKM-Ebola również podano pacjentom, a jego produkcja dofinansowana była przez Departament Obrony oraz firmę Monsanato, potentata na rynku żywności modyfikowanej genetycznie. Nie oznacza to jednak, że koncerny farmaceutyczne, które rozpoczęły starania o wprowadzenie leków czy szczepionek przeciwko eboli zrobiły to z myślą o mieszkańcach Afryki. Należy w tym miejscu powrócić do obserwacji Paula Farmera, który słusznie zwraca uwagę, że na większość występujących w Afryce chorób istnieją leki, jednak wciąż umierają na nie tysiące ludzi, ponieważ nikt nie chce sfinansować ich leczenia. Zatem można przypuszczać, że decyzja o rozpoczęciu produkcji leków wywołana była raczej paniką, jaka zapanowała w Stanach Zjednoczonych i Europie.

Epidemia eboli wyraźnie wskazuje, że problemów związanych $\mathrm{z}$ ochroną zdrowia nie da się rozwiązywać lokalnie; trzeba na nie spojrzeć z perspektywy globalnej. Jednak w kontekście Afryki pojęcie globalizacji jest problematyczne, ponieważ jest ona procesem łączącym jedynie wybrane punkty na kuli ziemskiej, przede wszystkim te, gdzie widoczny jest przepływ kapitału. James Ferguson określa ją jako „point-topoint connectivity" ${ }^{27}$, czyli sieć zależności i połączeń pomiędzy węzłami, które jako odzwierciedlenie przestrzeni, zawierają bardzo wiele miejsc, nie należących do tejże sieci. Po tym jak w latach 60. większość krajów w Afryce odzyskała niepodległość, spodziewano się, że poprzez inwestycje nastąpi ich znaczący rozwój gospodarczy i podniesienie poziomu życia, jednak z powodu niestabilnej sytuacji politycznej, w większości przypadków nie miało to miejsca. Państwa takie jak Sierra Leone, Gwinea czy Liberia należą do kategorii krajów, które na zglobalizowanej mapie świata stanowią raczej pustą przestrzeń pomiędzy głównymi węzłami przepływu kapitału, dlatego dopiero zachodnia panika medialna spowodowała, że społeczność międzynarodowa oraz koncerny farmaceutyczne w ogóle zainteresowały się wirusem ebola.

Jeśli jednak przyjrzymy się epidemii eboli jako problemowi związanemu nie tylko z ochroną zdrowia, ale szerzej, z ochroną środowiska, to paradoksalnie kraje takie jak Gwinea niespodziewanie pojawiają się na mapie globalnego przepływu kapitału. Są to wszakże miejsca, z których ów kapitał odpływa. I tutaj ponownie chciałabym powrócić do filmu, ukazującego ,przeklętą wioskę”, w której rozpoczęła się epidemia. Jednak tym razem proponuję, aby zastanowić się nad przyczyną, dla której osadę tę oprócz ludzi zamieszkują również nietoperze roznoszące ebolę. Wydaje mi się bowiem, że analiza przyczyn, dla których dzieci w tej wiosce miały kontakt z nietoperzami spowoduje kapitulację Niesamowitego (uncanny) na rzecz banalnej prozy życia jej mieszkańców uprawiających palmy.

W Gwinei dzikie plantacje palm (dura, pisifera oraz tenera) od dawna stanowiły źródło oleju palmowego, jednak w związku ze światowym zapotrzebowaniem na ten surowiec, od 2007 roku rząd postanowił zwiększyć jego produkcję. Proces ten odbywa się przede wszystkim poprzez powiększenie areału, na którym uprawiane są palmy, czego skutkiem jest deforestacja oraz zniszczenie naturalnego środowiska różnych gatunków dzikich zwierząt, w tym trzech gatunków nietoperzy, które prawdopodobnie są nosicielami wirusa eboli ${ }^{28}$. Jedną $\mathrm{z}$ firm działających $\mathrm{w}$ tym zakresie jest założona przez rząd w 1987 roku The Guinean Oil Plam and Rubber Company (SOGUIPAH), która systematycznie zatrudnia sezonowych robotników, negocjuje z rolnikami przejęcie ziemi, organizuje sieć odbiorców i wspierana przez lokalną policję, przegania rolników z pól, na których do tej pory uprawiali ryż, kawę czy gumę. Międzynarodowa pomoc ze strony Europejskiego Banku Inwestycyjnego przyśpieszyła te przemiany poprzez inwestycje w rozwój młyna, którego wydajność zwiększyła się czterokrotnie, co spowodowało pełne zatrudnienie wśród lokalnych rolników, jednak wyłącznie

${ }^{27}$ J. Ferguson, Global Shadows: Africa in the Neoliberal World Order, Durham 2006.

${ }^{28}$ Commentary, „Environment and Planning A”, 2014, t. 46, s. 2533-2542, http:// epn.sagepub.com/content/46/11/2533.full.pdf 
w sezonie zbiorów. Doprowadziło to do niemalże zupełnego zlikwidowania małych pół uprawnych oraz przekształcenia ich w bardziej opłacalne uprawy monokulturowe, czego konsekwencją jest to, że poza sezonem lokalni rolnicy nie mają się z czego utrzymywać. Procesy te wywołały upadek rolnictwa indywidualnego, ponieważ wszyscy rolnicy w regionie związani są kontraktem, za którego łamanie grożą im kary, oraz uzależnieni są od sieci odbiorców oleju palmowego zakontraktowanego przez przedsiębiorstwo rządowe. Co więcej, procesy te doprowadziły do zmian w zachowaniu nietoperzy, które migrują do ulokowanych blisko osiedli ludzkich pól palmowych oraz drzew owocowych, gdzie żerują oraz kryją się przed słońcem. Być może hipoteza o tym, że powodem zachorowania było zjedzenie mięsa nietoperza jest prawdziwa, jednak inna hipoteza mówi o tym, że drogą zakażenia mogły być owoce zbierane przez ludzi, zanieczyszczone wcześniej odchodami nietoperzy. Tak czy inaczej, jeśli przyjrzymy się zagadnieniu obecności nietoperzy w ,przeklętej wiosce” z punktu widzenia przepływu zagranicznego kapitału, to pozbawia to ów obraz aury niesamowitości obecnej w materiale zrealizowanym przez PBS i „The New York Times” i każe się zastanowić nad zakresem odpowiedzialności wspólnoty międzynarodowej. Odpowiedzialność ta nie jest bowiem ufundowana, jak wydają się sugerować medialne przedstawienia epidemii, na wartościach humanitarnych oraz solidarności międzyludzkiej, ale na rzeczywistym wpływie, jakie mają społeczeństwa zachodnie na życie i śmierć Emila oraz jego rodziny.

\section{Wiedza i władza}

Obydwa wystąpienia Baracka Obamy dzieli około 6 tygodni i wydaje się, że jeśli prześledzimy wydarzenia, które miały miejsce w tym czasie, to bardziej przejrzysta stanie się też retoryka, jaką posługuje się prezydent USA. Najważniejsze jest zdobycie informacji - twierdzi Obama. Z perspektywy krajów europejskich oraz Stanów Zjednoczonych Afryka może jawić się jako jedno, ubogie i skazane na biedę państwo, do którego obywateli nie docierają żadne informacje, zatem skłonni są oni zawierzyć swoje zdrowie przesądom i magicznym rytuałom. Jednak Afryka jest kontynentem, na którym znajdują się państwa o różnym stopniu rozwoju oraz skomplikowanej sytuacji politycznej.

I tak w Nigerii, w której najszybciej doszło do zatrzymania epidemii wirusa, sytuacja polityczna jest ustabilizowana, a ówczesny prezydent kraju Goodlack Jonathan bardzo szybko zareagował na doniesienie o pierwszym przypadku zakażenia ebolą ${ }^{29}$. W przeciągu kilku tygodni zorganizowano tam szeroko zakrojoną kampanię informacyjną, a centra, które wybudowano w związku z polio, przekształcono tak, aby mogły przyjmować chorych na ebolę. W kraju działa Africa Centre of Excellence for Genomics of Infectious Diseases, co umożliwiło szybkie potwierdzenie faktu, że faktycznie chodzi o wirus eboli, a nie o inne choroby tropikalne.

Warto w tym miejscu zaznaczyć, że Nigeria opisywana była przez media zachodnie jako kraj, w którym zatrzymanie eboli stanowiło sukces mediów społecznościowych, co wydaje się znaczącym uproszczeniem. Oczywiście nie da się zaprzeczyć, że odegrały one bardzo ważną rolę, przede wszystkim w dementowaniu fałszywych pogłosek o epidemii, upowszechnianiu wiedzy na temat źródeł zakażenia oraz budowaniu pozytywnego wizerunku pracowników służby zdrowia. Jednak mediów społecznościowych nie można traktować jako „magicznego pocisku”, ponieważ zamazuje to fakt, że za akcją informacyjną stali pracownicy służby zdrowia i aktywiści, którzy codziennie, przez cały okres trwania epidemii narażali swoje życie i zdrowie.

Upraszczające stwierdzenia tego typu pomijają to, że Nigeria ma jeden z najbardziej stabilnych rządów w Afryce. Natomiast Lagos, którego populacja wynosi ponad

${ }^{29}$ A. Corrigan, \#StopEbola: What Nigeria did right, „Berman Center for Internet and Society”, https://cyber.law.harvard.edu/events/luncheon/2015/01/Corrigan 
21 milionów ludzi, w związku z czym bardzo duże obszary tego miasta zajmują slumsy, posiada mimo wszystko dość dobrze rozwinięta infrastrukturę, do której należy zaliczyć sieć komórkową i łącza internetowe, ale przede wszystkim publiczne placówki służby zdrowia. Wydaje się, że retoryka sukcesu mediów społecznościowych w przypadku eboli, jest analogiczna do tej, jaka towarzyszyła wydarzeniom Arabskiej Wiosny, gdzie również mówiono o tym, że jest to „wytweetowana rewolucja”, a pełni entuzjazmu dziennikarze skłonni byli przyznać Tweeterowi pokojową Nagrodę Nobla.

O tym, że dostęp do informacji nie był najważniejszym czynnikiem, który wpłynął na to, jak rozwijała się epidemia, świadczyć może porównanie sytuacji w Nigerii $\mathrm{z}$ sytuacją $\mathrm{w}$ innych krajach, np. Liberii. Pierwszy rzut epidemii w tym państwie trwał dość krótko. W marcu i kwietniu odnotowano jedynie 12 śmiertelnych przypadków zachorowań, jednak 29 maja wirus pojawił się w stolicy kraju i tym razem epidemia rozpoczęła się $\mathrm{w}$ najlepsze. $\mathrm{W}$ celu zapobiegania rozprzestrzenieniu się wirusa pracownicy organizacji Lekarze bez Granic (MSF) oraz CDC wraz z miejscowym personelem medycznym stworzyli tymczasowe centra, gdzie możliwe było izolowanie chorych oraz ich bliskich, jak również izolowanie personelu medycznego, który miał z nimi kontakt. Zorganizowana została też szeroko zakrojona akcja informacyjna: w radiu pojawiały się ogłoszenia, na ulicach plakaty oraz ulotki, uruchomiono linię telefoniczną, gdzie można było zgłaszać przypadki zachorowań, a pracownicy służby zdrowia podróżowali do najdalej położonych wiosek, aby bezpośrednio poinformować ich mieszkańców o zagrożeniu oraz poinstruować, jak należy się przed nim chronić. W akcję informacyjną zaangażowany był Alfred J. Sirleaf, który od kilkunastu lat prowadzi tzw. tablicową gazetę, dzięki której niepiśmienni mieszkańcy mogą zapoznać się z najważniejszymi wydarzeniami ${ }^{30}$.

Jednak do mediów zachodnich dotarły głównie sceny, które miały miejsce pod koniec sierpnia, dwa tygodnie przed wystąpieniem Obamy. Na zdjęciach z 20 sierpnia 2014 roku wykonanych w slumsowej dzielnicy West Point, położonej na obrzeżach stolicy kraju widać piętnastoletniego Shaki Kamarę. Leży on na chodniku postrzelony w obydwie nogi. Umrze następnego dnia, choć, jak wynika $\mathrm{z}$ raportu The Independent National Human Rights Commission, tego typu incydent nie powinien mieć miejsca. Komisarz policji odpowiedzialny za tłumienie protestów w West Point oświadczył, że policja wprawdzie użyła broni palnej, ale strzelała w powietrze, jednak z raportu wynika, że służby porządkowe musiały celować do protestujących, o czym świadczą rany postrzałowe w brzuch oraz nogi, których doznali demonstranci.

Relacje $\mathrm{z}$ tego wydarzenia wyrwane były $\mathrm{z}$ kontekstu. Przedstawiały one kwarantannę jako jedyny słuszny środek zapobiegawczy, a brutalną interwencję policji jako uzasadnioną. Rzadko pojawiały się w mediach bardziej dogłębne analizy, które osadzałyby te wydarzenia w kontekście społeczno-politycznym. Do wyjątków należy film dokumentalny The Fight Against Ebola zrealizowany również przez Vice Media, w którym wspomniana jest wojna domowa w Liberii, jako potencjalna przyczyna nieufności mieszkańców West Point względem rządu ${ }^{31}$. Nie jest to bynajmniej pogłębiona analiza, jednak od czerwca, kiedy Vice Media zrealizowało pierwszy materiał na temat jedzenia mięsa dzikich zwierząt oraz niewiary Liberyjczyków w istnienie wirusa, widać pewną zmianę retoryki. Być może dlatego, że przebywający w październiku w terenie dziennikarz został wrzucony w samo epicentrum rozgrywającego się na jego oczach dramatu. Tłumy chorych, którym nie udzielano pomocy, umierały na chodnikach przed polowymi szpitalami MSF i szpitalem JFK, ponieważ nie było tam dla nich miejsca. W niemalże 30 minutowym filmie znajduje się około 30 sekundowa sekwencja składa-

${ }^{30}$ O. Quist-Arcton, Liberia's Daily Talk: All The News That Fits On A Blackboard, „Goats and Soda. Stories of Life in a Changing World“, http://www.npr.org/sections/ goatsandsoda/ 2014/12/12/370154232/liberias-daily-talk-all-the-news-that-fits-on-a-blackboard

${ }^{31}$ The Fight Against Ebola, https://www.youtube.com/watch?v=ANUI4uT3xJI 
jąca się ze zdjęć archiwalnych ukazujących wojnę domową, a komentarz łączy je z wydarzeniami, które miały miejsce w West Point.

Tragiczne zajście w West Point stanowi część sekwencji wydarzeń zapoczątkowanych cztery dni wcześniej, kiedy grupa mieszkańców napadła na budynek szkoły, gdzie w związku z rosnącą lawinowo liczbą zachorowań na ebolę zorganizowano prowizoryczną przychodnię stanowiącą miejsce izolacji tych, dla których nie było miejsca w szpitalach. Z powodu braku podstawowych leków, takich jak aspiryna czy kroplówki nawadniające, chorym nie udzielano żadnej pomocy medycznej. Podczas napadu skradziono skromne zapasy środków medycznych, generator prądu oraz używaną pościel i materace, co wzbudziło obawy, że staną się one dalszym źródłem rozprzestrzeniania się wirusa. Kilkunastu chorych $\mathrm{z}$ pomoca swoich bliskich samowolnie opuściło przychodnię i schroniło się w slumsach. Bezradna prezydent Liberii Shirleaf zdecydowała się poddać ludność West Point kwarantannie. W nocy, nie uprzedzając mieszkańców, zablokowano więc drogi, a wojsko i policja pilnowały, aby nikt nie mógł wejść ani wydostać się z terenu odgrodzonego kordonem sanitarnym. Jedynymi ludźmi, którym udało się wydostać z potrzasku był Miatta Flowers, pracujący dla rządu zarządca West Point oraz jego rodzina, co jeszcze bardziej rozwścieczyło zgromadzony wewnątrz tłum, na który składali się między innymi byli żołnierze, funkcjonujący na marginesie życia społecznego od czasu zakończenia wojny domowej ${ }^{32}$.

Ludzie wyszli na ulice, ponieważ zaczęło brakować jedzenia, które w związku z tym osiągnęło horrendalne ceny. Dawid Gilkey, jeden z niewielu fotoreporterów zachodnich, który był podczas zamieszek w West Point, zapytany o wrażenia, nawiązywał do zamieszek w Ferguson, które wybuchły po zastrzeleniu czarnego nastolatka Michaela Browna przez policjanta Darrena Wilsona:

Jestem trochę oszołomiony. To jest o prostu szaleństwo. Pomyśl o tym, jak robi się materiał o zamieszkach, kiedy sytuacja jest napięta. Wyobraź sobie to, co dzieje się w Missouri. A następnie dodaj do tego ebolę. ${ }^{33}$

Zdarzały się jednak artykuły, które doszukiwały się głębszych, strukturalnych przyczyn wydarzeń, jakie miały miejsce w West Point, czego przykładem jest tekst Helen Epstein. Dziennikarka, która odwiedziła Monrovie we wrześniu, w artykule dla „The New York Review of Books”, odnosząc się do tych wydarzeń pisała, że powody, dla których epidemia eboli uderzyła szczególnie mocno w Liberię, były przede wszystkim polityczne ${ }^{34}$. Kryzys spowodowany był nieufnością Liberyjczyków względem prezydent Shirleaf oraz jej rządu, co wywołało zamieszki i szerzenie się plotki, która rzekomo wyjaśniała pojawienie się eboli. Plotka ta głosiła również, że tajemnicza choroba dziesiątkująca na początku roku całe wioski wywołana była trucizną wytworzoną przez prezydent Shirleaf po to, aby zabić jak najwięcej osób, dzięki czemu do kraju popłynąć miały fundusze $\mathrm{z}$ międzynarodowych organizacji takich jak UN, które co wielokrotnie miało już miejsce - zostaną zdefraudowane przez skorumpowanych polityków. Shirleaf, z wykształcenia ekonomistka, której działalność opozycyjna przyczyniła się do obalenia Charlesa Taylora, uhonorowana została pokojową Nagrodą Nobla i doceniana jest przez zachodnich polityków za ustabilizowanie sytuacji politycznej w Liberii, wcześniej przez 23 lata ogarniętej wojną domową.

Prezydent Shirleaf, prowadząc politykę proamerykańską, opisywana jest przez zachodnie media, jako jedna z postaci kluczowych dla pokojowych przemian zachodzą-

${ }^{32}$ J. Söderström, Ebola and the Ex-Combatant Community, „Cultural Anthropology Journal“ 2014, t. 10, http://www.culanth.org/fieldsights/601-ebola-and-the-ex-combatant-community

${ }^{33}$ D. Gilkey, Riot Erupts Over Ebola Quarantine In Liberia, „Goats and Soda. Stories of Life in a Changing World", http://www.npr.org/sections/goatsandsoda/2014/08/20/341884494/ photographing-an-ebola-riot-put-your-fear-aside-and-go-forward

${ }^{34}$ H. Epstein, Ebola in Liberia, An Epidemic of Rumors, „The New York Review of Books, 18.12.2014, http://www.nybooks.com/articles/2014/12/18/ebola-liberia-epidemic-rumors/ 
cych w Afryce Zachodniej. Jednak to właśnie brak zaufania względem jej rządu był jedną z przyczyn, dla których z podejrzliwością podchodzono do informacji przekazywanych przez pracowników służby zdrowia. Oskarżano ich między innymi o to, że na polecenie prezydent, zamiast pomagać chorym rozprzestrzeniali chorobę. Ta spiskowa teoria nie była rozpowszechniana jedynie na prowincji, ponieważ również w lokalnych gazetach i radio w Monrovi pojawiały się informacje o tym, że epidemia eboli jest jedynie medialną mistyfikacją, która ma na celu „wyłudzenie” funduszy od organizacji międzynarodowych zajmujących się pomocą.

Również w Gwinei - w stolicy oraz na prowincji - zauważalny był brak zaufania względem pracowników służby zdrowia oraz przekonanie, że istnienie wirusa jest jedynie plotką. Doprowadziło to do śmierci sześciu lekarzy, którzy zostali zabici przez przestraszonych ich wyglądem mieszkańców wioski Wome położonej na południu kraju ${ }^{35}$. Niekiedy ukrywać musieli się również zachodni dziennikarze, którzy udali się do Gwinei, aby pisać o przebiegu epidemii ${ }^{36}$.

Analizując rolę mediów - zarówno tradycyjnych jak i społecznościowych - należy mieć na uwadze to, że system medialny w danym kraju nie funkcjonuje w społecznopolitycznej pustce. Owszem, w przypadku choroby takiej jak ebola najważniejsze jest poznanie faktów, jednak trzeba wziąć również pod uwagę stopień zaufania ludzi względem źródła informacji. Ów stopień zaufania nie jest jedynie uzależniony od rzetelności czy przystępności przekazywanych informacji, ale przede wszystkim od tego, kto jest nadawcą komunikatu. Dlatego nie należy bagatelizować takich zjawisk, jak tablicowa gazeta Shirleafa, która, choć ma nieporównywalnie mniejszy zasięg niż serwisy społecznościowe i przedstawia informacje w sposób uproszczony, cieszy się zaufaniem swoich odbiorców w przeciwieństwie do źródeł rządowych. Poza tym pisząc o zasięgu mediów społecznościowych, należy wziąć pod uwagę to, w jakim stopniu rozwinięta jest infrastruktura informacyjna w danym kraju, w związku z czym nie można porównywać Nigerii z Sierra Leone, Liberią czy Gwineą. Można natomiast zastanowić się, jak kształtowałaby się sytuacja, gdyby epidemia nie miała miejsca w Lagos, ale na przykład na terenach, które znajdują się w strefie wpływów grupy Boko Haram. Wzięcie pod uwagę kontekstu politycznego uświadamia $\mathrm{z}$ jednej strony, że nie ma jednego dobrego sposobu na walkę $\mathrm{z}$ chorobą taką jak ebola, a $\mathrm{z}$ drugiej strony naświetla powody nieufności względem informacji przekazywanych drogami oficjalnymi i tym samym pozwala zrozumieć niechętny stosunek obywateli Sierra Leone czy Gwinei względem pracowników służby zdrowia, którego nie można sprowadzić jedynie do kategorii działań irracjonalnych, wynikających $\mathrm{z}$ niewiedzy czy uprzedzenia.

\section{Najważniejsze jest poznanie faktów}

Zachodnie media relacjonując przebieg epidemii eboli, skupiły się przede wszystkim na kulturze dotkniętych nią krajów, opisując ją jako jeden z najważniejszych czynników ryzyka. Dziennikarze wykreowali obraz zacofanej Afryki, której mieszkańcy są nieufni względem zachodniej medycyny i wbrew zdrowemu rozsądkowi kultywują swoją tradycję. Tymczasem zadaniem mediów powinno być edukowanie publiczności, szczególnie $\mathrm{w}$ przypadku zagrożenia dla bezpieczeństwa publicznego, jakim z pewnością była epidemia eboli. Zgadzam się z prezydentem Obamą, że poznanie faktów jest najważniejsze, ale dotyczy to w takim samym stopniu mieszkańców Zachodniej Afryki, co mieszkańców Zachodniej Europy czy Stanów Zjednoczonych, którzy mają prawo rozumieć, dlaczego konieczne jest, aby kraje zachodnie zaangażowały się w walkę $\mathrm{z}$ epidemią. Tymczasem media, relacjonując przebieg epidemii, kolejny raz $\mathrm{w}$ historii dopuściły się aktu przemocy symbolicznej, wpisując Afrykę w dobrze znaną figurę „innego”, zamiast skupić się na analizie mechanizmów przemocy, określanej przez

${ }^{35}$ Ebola outbreak: Guinea health team killed, BBC News, 19.9.2014, http://www. bbc.com/news/world-africa-29256443

${ }^{36}$ Ibidem. 
Farmera mianem ,„przemocy strukturalnej”, ${ }^{37}$. Zresztą Farmer w jednej ze swych wypowiedzi, podkreślając odpowiedzialność społeczności międzynarodowej za epidemię, stwierdził, że ebola nie jest fenomenem naturalnym, ale aktem terroru wynikającym $\mathrm{z}$ ubóstwa dotkniętych nią krajów ${ }^{38}$.

Przemoc strukturalna to sposób opisywania porządku społecznego, który jest krzywdzący dla jednostek oraz całej populacji. Określa się ją jako strukturalną, ze względu na to, że wpisana jest w układy polityczne i ekonomiczne, które wyewoluowały w procesie historycznych przemian kształtujących poszczególne społeczeństwa. Przemoc strukturalna paraliżuje działania jednostek oraz rządów mające na celu poprawe warunków socjalnych. Polega ona zarazem na tym, że niemożność poprawy sytuacji w zakresie dostępu do służby zdrowia czy edukacji uzasadnia się często brakiem aspiracji jednostek oraz społeczeństw. Podczas panelu poświęconego eboli, który miał miejsce na MIT, Jeanne Guillemin, Clapperton Mavhunga i Adia Benton podkreślali, że wprawdzie jest to pierwsza epidemia eboli, jednak nie jest to pierwsza epidemia w historii świata i powinno się wyciągać wnioski z epidemii polio, ospy, czy AIDS, co niestety nie miało miejsca ${ }^{39}$.

\section{JOANNA WALEWSKA}

\section{THE MAKING OF EBOLA... MEDIA NARRATIVES ABOUT THE EPIDEMIC IN WEST AFRICA}

\section{SUMMARY}

The article focuses on Western media narratives about the 2014 Ebola virus epidemic in West Africa. The author analyzes selected media texts to show the way in which Africa is represented as a land doomed to poverty and as "a reservoir of the virus." She also shows that the Western media providing the information on the epidemic often omitted social, political, and economic factors from which the epidemic originated. Instead they emphasized local customs (burial rituals, eating wild animals' meat, magical rituals) as the most significant risk factors. Not mentioning the lack of medical infrastructure or the poverty in the affected countries, which was caused by a particular geopolitical situation, made the Ebola epidemic seem a natural phenomenon that could not have been avoided.

Translated by Justyna Deszcz-Tryhubczak

${ }^{37}$ Zob. P. Farmer, Never Again? Reflections on Human Values and Human Rights, University of Utah, March 30, 2005; P. Farmer, An Anthropology of Structural Violence, „Current Anthropology", 2004, t. 45, nr 3, s. 305-325.

J. Achenbach, Paul Farmer on Ebola: "This isn't a natural disaster, this is the terrorism of poverty”, „The Washington Post“, 6.10.2014, https://www.washing tonpost.com/ news/achenblog/wp/2014/10/06/paul-farmer-on-ebola-this-isnt-a-natural-disaster-this-is-the-terrorismof-poverty/.

Examining Ebola Interdisciplinary Panel, MIT School of Humanities, Arts, \&Social Sciences, https://shass.mit.edu/multimedia/video-2014-examining-ebola-interdisciplinary-panel 